\title{
Insulin Resistance in a Boy with Congenital Generalized Lipodystrophy
}

\author{
HIROKAZU TSUKAHARA, KIYOSHI KIKUCHI, HIDESHI KUZUYA, EIKO ITO, YOKO ODA, \\ ATSUSHI KOSAKI, TAKAKO KAKEHI, HARUO NISHIMURA, KAZUNURI YAMADA, \\ YASUNAO YOSHIMASA, HIROO IMURA, AND HARUKI MIKAWA \\ Department of Pediatrics [H.T., K.K., H.M.], Second Division, Department of Medicine [H.K., A.K., T.K., H.N., \\ K.Y., Y.Y., H.I.], Kyoto Municipal Toyo Hospital [E.I., Y.O.], Kyoto, Japan
}

\begin{abstract}
We have studied insulin resistance in a 12year-old Japanese boy who presented with congenital generalized lipodystrophy. Oral glucose tolerance test exhibited a diabetic pattern with normal fasting plasma glucose. Results from euglycemic glucose clamp study showed decreases in both insulin sensitivity and responsiveness. Both the patient's erythrocytes and Epstein-Barr virus transformed lymphocytes showed low-normal insulin binding with a slight reduction in binding affinity in the latter. Insulin binding to the cultured fibroblasts was decreased due to a lowered affinity. In addition, they displayed a rightward shift of the insulin dose-response curve for D${ }^{14} \mathrm{C}$-glucose uptake with no decrease in the maximum uptake. Insulin-stimulated autophosphorylation and kinase activity of the wheat germ agglutinin purified receptors from the Epstein-Barr virus-transformed lymphocytes appeared normal. The reason for some discrepancies in insulin binding among the cells remains unknown, and we cannot formulate a conclusion as to whether or not a primary binding defect of insulin receptors exists and contributes to insulin resistance in the patient. The decrease in insulin responsiveness demonstrated in the glucose clamp study may result from a defect at the rate-limiting step in the postbinding process of insulin action, presumably a defect in the glucose transport system in muscle tissues. The defect may be secondary to changes in in vivo circumstances. (Pediatr Res 24: 668-672, 1988)
\end{abstract}

\section{Abbreviations}

CGL, congenital generalized lipodystrophy

EBV, Epstein-Barr virus

WGA, wheat germ agglutinin

src, the gene responsible for transformation by Rous sarcoma virus

BSA, bovine serum albumin

gMCR, steady-state glucose metabolic clearance rate

$\mathrm{B} / \mathrm{T}$, ratio of bound to total ${ }^{125}$ I-insulin

Ro, total receptor number

Ke, binding affinity constant

IBC, insulin binding capacity

HGP, hepatic glucose production

ID $_{50}$, insulin concentration necessary to obtain the halfmaximum inhibition of specific binding.

Received February 24, 1988; accepted July 27, 1988

Correspondence Kiyoski Kikuchi, M.D., Department of Pediatrics, Shimane Medical University, 89-1 Enya-cho, Izumo 693, Japan.
CGL, a rare hereditary disease, was first documented by Berardinelli (1) and Seip (2). The clinical features are observed from birth or early infancy, and the hallmarks include a total lack of fatty tissue, peculiar face, accelerated growth, muscular hypertrophy, acanthosis nigricans, hepatomegaly, and hypertrophied genitals (1-10). In CGL, normal glucose tolerance is observed during the first few years of life. However, between the ages of 7 and 12 $y r$, glucose intolerance ensues and insulin-resistant and nonketotic diabetes mellitus develops in most cases $(6-10)$. The reason for insulin resistance in CGL remains unknown. Previous studies on the insulin resistance have yielded conflicting results $(6-10)$.

In this paper, we report the case of a 12-yr-old Japanese boy with CGL who showed insulin resistance. To gain further insight into the mechanisms of the insulin resistance, we performed euglycemic glucose clamp studies and investigated insulin binding to circulating erythrocytes, cultured skin fibroblasts and EBVtransformed lymphocytes. Similarly, we estimated insulin-stimulated autophosphorylation and kinase activity of WGA-purified receptors from the EBV-transformed lymphocytes and insulinstimulated glucose incorporation into the cultured fibroblasts using $\mathrm{D}-{ }^{14} \mathrm{C}$-glucose.

\section{PATIENT}

The patient had been born to healthy and unrelated parents after a 41-week uncomplicated term pregnancy and normal delivery. His weight at birth was $2040 \mathrm{~g}$; his length $45 \mathrm{~cm}$. At birth, he was noticed to have a generalized deficiency of subcutaneous fat and a short, peculiar face, which was characterized by large eyes, hollow cheeks, micrognathia and mandibular prognathism. Developmental milestones were normal (head control at 4 months, crawl at 8 months, walk alone at 15 months, and speech at 12 months). Between the ages of 8 and $12 \mathrm{yr}$, he was hospitalized at the Kyoto Municipal Toyo Hospital for the treatment of bronchial asthma. At age $8 \mathrm{yr}$, bone age was $5 \mathrm{yr}$, based on the criteria of Greulich and Pyle. At age $10 \mathrm{yr}$, pubic hair appeared. At age $12 \mathrm{yr}$, glucosuria was noticed, and hyperpigmentation of the skin in the bilateral axillae appeared.

Based on the above-mentioned clinical findings, he was diagnosed as CGL and referred to Kyoto University School of Medicine Hospital at $12 \mathrm{yr}, 7$ months of age for further evaluations. Informed consent for all studies was obtained from the patient and his parents. There was no family history of diabetes mellitus, lipodystrophy, or peculiar face. He had a weight of 26.5 $\mathrm{kg}(-1.9 \mathrm{SD})$, a height of $141 \mathrm{~cm}(-1.3 \mathrm{SD})$, and a head circumference of $48 \mathrm{~cm}(-3.4 \mathrm{SD})$. His peculiar face gave him an elderly look. Subcutaneous fatty tissue was diminished everywhere, especially in the face and extremities, and superficial veins were prominent in the extremities. Hyperpigmented skin lesions were present in the bilateral axillae, and the findings of histolog- 
ical examination were compatible with those of acanthosis nigricans. His bilateral fifth fingers were short and were similarly observed in his mother. He did not have cardiomegaly but presented mild hepatomegaly. His pubertal development was at stage IV (Tanner's criteria), and bone age was $14 \mathrm{yr}$. Phallic enlargement was not observed. Karyotype was 46 XY. He had mild perceptive hearing disturbance.

Hematologic study and liver and renal function tests yielded normal results. He had increased serum concentration of immunoglobulin E $(1297 \mathrm{IU} / \mathrm{ml})$, and cold activation of complement system was observed $\left(\mathrm{CH}_{50}:<4.3 \mathrm{U} / \mathrm{ml}\right.$ in serum and 45.1 $\mathrm{U} / \mathrm{ml}$ in plasma after freezing). Hyperlipidemia was not observed (serum total cholesterol, triglyceride, and free fatty acid concentrations: $138 \mathrm{mg} / \mathrm{dl}, 92 \mathrm{mg} / \mathrm{dl}$, and $370 \mu \mathrm{Eq} /$ liter after overnight fasting, respectively). Oral glucose tolerance test $(1.75 \mathrm{~g} / \mathrm{kg}$ of glucose) revealed that plasma glucose concentration increased from $108 \mathrm{mg} / \mathrm{dl}$ to $248 \mathrm{mg} / \mathrm{dl}$ (at $120 \mathrm{~min}$ ) and that serum insulin concentration increased from 34.9 to $251 \mu \mathrm{U} / \mathrm{ml}$ (at 120 min). A bolus injection of exogenous insulin $(1.0 \mathrm{U} / \mathrm{kg}$, intravenously) showed no remarkable reduction in plasma glucose concentrations. Neither anti-insulin nor anti-insulin receptor antibodies were found in the patient's plasma, and the concentrations of circulating insulin antagonists, i.e. glucagon, growth hormone, and cortisol were not elevated. These findings suggested that insulin resistance in the patient was due to a target cell defect in insulin action.

\section{MATERIALS AND METHODS}

Reagents. $\mathrm{Na}^{-125} \mathrm{I}$ and $\left[\gamma_{-}{ }^{32} \mathrm{P}\right] \mathrm{ATP}$ were purchased from New England Nuclear and src-related peptide, Arg-Arg-Leu-Ile-GluAsp-Ala-Glu-Tyr-Ala-Ala-Arg-Gly, was from Peninsula Laboratories, Inc. WGA sepharose was obtained from Pharmacia (Piscataway, NJ). Reagents for sodium dodecyl sulfate-polyacrylamide gel electrophoresis were purchased from Bio-Rad. $\alpha$ minimum essential medium, RPMI-1640 medium, trypsin and fetal calf serum were from Flow Laboratories, Inc. HEPES, Tricine, tris, phenylmethyl sulfonyl fluoride, $\mathrm{N}$-acetyl-D-glucosamine, BSA and bovine $\gamma$-globulin were from Sigma. Porcine insulin was from Novo Inc., and Triton X-100 was from Wako Chemical Co. All other chemicals used were reagent grade.

Porcine insulin was iodinated by the chloramine $\mathrm{T}$ method with a specific activity of 110 to $220 \mu \mathrm{Ci} / \mu \mathrm{g}$ and purified on a Sephadex G-75 column $(1 \times 60 \mathrm{~cm})$.

Euglycemic Glucose Clamp Technique. In vivo peripheral insulin action was measured using the euglycemic glucose clamp technique as previously described by Greenfield et al. (11). The study was performed with two different rates of insulin infusion. Insulin was initially infused at $40 \mathrm{mU} / \mathrm{m}^{2} / \mathrm{min}$ and thereafter raised to $200 \mathrm{mU} / \mathrm{m}^{2} / \mathrm{min}$. Blood glucose concentration was held constant at the basal level by a variable glucose infusion using the negative feedback principle. Because basal blood glucose concentrations varied among the subjects, we used the gMCR, which was calculated by dividing the glucose infusion rate by the steady-state plasma glucose concentration $(11,12)$. Controls were five healthy 20 -yr-olds.

Cell Culture. Skin fibroblast lines were established from forearm incision biopsy. Cells were cultured as monolayers in a $\mathrm{CO}_{2}$ incubator with $\alpha$ minimum essential medium supplemented with $10 \%$ fetal calf serum.

Lymphoblastoid cell lines were established by infecting peripheral blood lymphocytes with EBV (conditioned medium of marmoset B95-8 cells) (13). Cells were grown in RPMI 1640 medium supplemented with $10 \%$ heat-inactivated fetal bovine serum and antibiotics. All studies were performed when cells were in late $\log$ phase growth.

Insulin-Binding Assay. Insulin binding was performed on circulating erythrocytes, monolayer cultures of skin fibroblasts, and EBV-transformed lymphocytes according to the methods of
Gambhir et al. (14), Baldwin et al. (15) and Taylor et al. (13), respectively.

In the figures, $\mathrm{B} / \mathrm{T}$ was plotted as a function of total insulin concentration. All the insulin-binding data were analyzed by the method of Scatchard (16). Ro and $\mathrm{Ke}$ were calculated from Scatchard plots by the method of De Meyts et al. (17). The insulin binding data were also analyzed by the two binding-site model (18).

Phosphorylation Assays of the WGA-Purified Insulin Receptors from EBV-Transformed Lymphocytes. Solubilization and partial purification of insulin receptors from EBV-transformed lymphocytes was performed as described by Grunberger et al. (19). Insulin binding to the WGA-purified receptors was carried out according to the method of Hedo et al. (20). Data on autophosphorylation and kinase activity were expressed as the amount of ${ }^{32} \mathrm{P}$ incorporated into the $\beta$-subunit and an exogenous substrate per IBC, respectively.

In vitro autophosphorylation of the $\beta$-subunit. Ninety microliters of the WGA-purified receptor preparation was preincubated with or without insulin $\left(10^{-10}\right.$ to $\left.10^{-6} \mathrm{M}\right)$ at $22^{\circ} \mathrm{C}$ for $45 \mathrm{~min}$. Phosphorylation was then commenced by incubating the mixture with 40 to $50 \mu \mathrm{M}\left[\gamma_{-}{ }^{32} \mathrm{P}\right] \mathrm{ATP}, 3 \mathrm{mM} \mathrm{MnCl}_{2}$ and $10 \mathrm{mM} \mathrm{NaF}$ at $22^{\circ} \mathrm{C}$ for $15 \mathrm{~min}$. The reaction was terminated by adding $5-$ fold concentrated Laemmli's sample buffer with $500 \mathrm{mM}$ dithiothreitol. The mixture was then boiled for $5 \mathrm{~min}$ and subjected to sodium dodecyl sulfate-polyacrylamide gel electrophoresis (7.5\% resolving gel). After electrophoresis, the gels were stained with Coomasie blue, destained, and autoradiographed. Molecular weight was estimated using protein standards composed of myosin, $\beta$-galactosidase, phosphorylase b, BSA and ovalbumin. The molecular mass $=95,000$ protein bands were excised and counted by a liquid scintillation counter. Control cells were obtained from eight healthy subjects with a mean ( \pm SD) age of $36.8 \pm 18.4$ yr.

Phosphorylation assay of src-related peptide. src-Related peptide was used as an exogenous substrate, and the assay was performed as previously described (21). In brief, $90 \mu$ l of WGApurified receptor preparation was preincubated at $22^{\circ} \mathrm{C}$ for 45 min with or without insulin $\left(10^{-7} \mathrm{M}\right)$ in a total volume of 100 $\mu$ l. After the mixture was incubated with $5 \mathrm{mM}$ ATP for an additional $10 \mathrm{~min}$ at $22^{\circ} \mathrm{C}$, phosphorylation was commenced by incubating the mixture with $1.5 \mathrm{mM}$ src-related synthetic peptide and 30 to $40 \mu \mathrm{M}\left[\gamma-{ }^{32} \mathrm{P}\right] \mathrm{ATP}$ at $22^{\circ} \mathrm{C}$ for $15 \mathrm{~min}$, in a final volume of $170 \mu \mathrm{l}$ of $50 \mathrm{mM}$ tris- $\mathrm{HCl}$ buffer, $\mathrm{pH} \mathrm{7.6,} \mathrm{containing}$ $3 \mathrm{mM} \mathrm{MnCl}_{2}$ and $10 \mathrm{mM} \mathrm{NaF}$. The reaction was terminated by the addition of $40 \mu \mathrm{l}$ of $1 \% \mathrm{BSA}$ and $50 \mu \mathrm{l}$ of $10 \%$ (wt/vol) trichloroacetic acid. The assay tube was ice-chilled for $30 \mathrm{~min}$, and then centrifuged in a Beckman Microfuge B for 4 min. Forty microliters of the supernatant fluid were spotted onto phosphocellulose paper, washed in acetic acid, dried, and counted in a liquid scintillation counter. Control cells were obtained from four healthy subjects with a mean $( \pm \mathrm{SD})$ age of $35.0 \pm 16.4 \mathrm{yr}$.

Glucose Incorporation Study. D-[U- $\left.{ }^{14} \mathrm{C}\right]$ glucose $(0.5 \mathrm{mM}, 1$ $\mu \mathrm{Ci} / \mathrm{ml})$ uptake to monolayer cultures of fibroblasts was measured in triplicate at $37^{\circ} \mathrm{C}$ for $20 \mathrm{~min}$, as described by Howard et al. (22). Control cells were obtained from four healthy subjects with a mean $( \pm S D)$ age of $29.0 \pm 2.6$ years.

Protein Assay. Protein content was determined with a BioRad protein assay Kit (Bio-Rad Laboratories) using BSA as a standard.

\section{RESULTS}

Euglycemic Glucose Clamp Technique. With the low-dose insulin infusion $\left(40 \mathrm{mU} / \mathrm{m}^{2} / \mathrm{min}\right)$, the steady-state plasma insulin concentration reached to $93.0 \mu \mathrm{U} / \mathrm{ml}$ in the patient, which was comparable to those of the controls (mean $\pm \mathrm{SD}=105.5 \pm$ $23.9 \mu \mathrm{U} / \mathrm{ml})$. Under this condition, the gMCR (gMCR $40: 4.6 \mathrm{ml} /$ $\mathrm{kg} / \mathrm{min}$ ) was low compared with the controls (mean $\pm \mathrm{SD}=9.0$ 
\pm 2.4 , range $=6.1 \sim 11.4 \mathrm{ml} / \mathrm{kg} / \mathrm{min}$ ). With the high-dose insulin infusion $\left(200 \mathrm{mU} / \mathrm{m}^{2} / \mathrm{min}\right)$, the steady-state plasma insulin concentration reached to a value $(1233 \mu \mathrm{U} / \mathrm{ml})$ higher than the controls (mean $\pm \mathrm{SD}=862.9 \pm 243.5 \mu \mathrm{U} / \mathrm{ml}$ ), but the gMCR (gMCR $200: 8.7 \mathrm{ml} / \mathrm{kg} / \mathrm{min}$ ) was decreased compared with the controls (mean $\pm \mathrm{SD}=14.8 \pm 3.0$, range $=11.3 \sim 19.1 \mathrm{ml}$ / $\mathrm{kg} / \mathrm{min}$ ). Previous studies (23) showed that insulin infusion at $200 \mathrm{mU} / \mathrm{m}^{2} / \mathrm{min}$ yielded almost near-maximum glucose disposal. To see if this is the case with our patient, an additional glucose clamp study was performed on the patient with a higher insulin infusion rate $\left(800 \mathrm{mU} / \mathrm{m}^{2} / \mathrm{min}\right)$. This study demonstrated a slight increase in gMCR to $10.5 \mathrm{ml} / \mathrm{kg} / \mathrm{min}$. The ratio of gMCR obtained at low-dose $\left(40 \mathrm{mU} / \mathrm{m}^{2} / \mathrm{min}\right)$ to the maximum gMCR (max gMCR: gMCR at $200 \mathrm{mU} / \mathrm{m}^{2} / \mathrm{min}$ for the controls and that at $800 \mathrm{mU} / \mathrm{m}^{2} / \mathrm{min}$ for the patient) was decreased in the patient (0.44) compared with the controls (mean $\pm \mathrm{SD}=0.61 \pm 0.08$, range $=0.54 \sim 0.74$ )

Insulin-Binding Studies. The specific binding $(\mathrm{B} / \mathrm{T})$ to circulating erythrocytes at a tracer amount of ${ }^{125} \mathrm{I}$-insulin $\left(3 \times 10^{-11}\right.$ $\mathrm{M})$ was in the lower part of normal range (Fig. $1 A$ ). Scatchard analysis of the binding data shows that insulin binding to the circulating erythrocytes was within normal values, with respect to both total receptor number and binding affinity (Table 1).

The specific binding $(\mathrm{B} / \mathrm{T})$ to cultured fibroblasts at a tracer amount of ${ }^{125}$ I-insulin $\left(7.5 \times 10^{-11} \mathrm{M}\right)$ was decreased in the patient (Fig. $1 B$ and Table 1 ). The decreased insulin binding was attributed mainly to a lowered receptor affinity.

The specific binding (B/T) to EBV-transformed lymphocytes at a tracer amount of ${ }^{125}$ I-insulin $\left(4.5 \times 10^{-11} \mathrm{M}\right)$ was in the lower part of normal range (Fig. 1C). As shown in Table 1, receptor affinity was slightly decreased.

Two binding-site analyses on cultured fibroblasts and lymphocytes showed that the number of low-affinity sites was increased in the patient compared with the controls (data not shown). The results were in agreement with those obtained from the analysis of binding by De Meyts et al.

Phosphorylation Assays of the WGA-Purified Insulin Receptors from EBV-Transformed Lymphocytes. In vitro autophosphorylation of the $\beta$-subunit. Autoradiograms of in vitro autophosphorylation using the WGA-purified receptor preparation demonstrated that the protein with molecular weight of $95,000(\beta$ subunit) was dominantly phosphorylated by the preincubation with insulin. Autophosphorylation of the $\beta$-subunit reached to the maximum at $10^{-7} \mathrm{M}$ of insulin in each subject. The basal ${ }^{32} \mathrm{P}$ incorporation value was undetectable in the patient (controls, mean $\pm \mathrm{SD}=0.12 \pm 0.06$, range $=0.05 \sim 0.19^{32} \mathrm{P} \mathrm{mol} / \mathrm{mol}$. IBC). Insulin $\left(10^{-7} \mathrm{M}\right)$ stimulated the autophosphorylation maximally to $0.33^{32} \mathrm{P} \mathrm{mol} / \mathrm{mol} \cdot \mathrm{IBC}$, which was within normal range (controls, mean $\pm \mathrm{SD}=0.57 \pm 0.29$, range $=0.29 \sim 0.99{ }^{32} \mathrm{P}$ $\mathrm{mol} / \mathrm{mol} \cdot \mathrm{IBC})$. The insulin dose-response curve for autophosphorylation in the patient was almost superimposable to those of the controls.

Phosphorylation assay of src-related peptide. We used the insulin concentration of $10^{-7} \mathrm{M}$, which gave maximum autophosphorylation as described above. Both the basal $\left(8.66^{32} \mathrm{P}\right.$ $\mathrm{mol} / \mathrm{mol}$. IBC) and maximally insulin-stimulated phosphorylation $\left(43.55{ }^{32} \mathrm{P} \mathrm{mol} / \mathrm{mol} \cdot \mathrm{IBC}\right)$ of src-related peptide were within normal ranges (controls, basal: mean $\pm \mathrm{SD}=14.15 \pm 3.49$, range $=2.44 \sim 18.95^{32} \mathrm{P} \mathrm{mol} / \mathrm{mol} \cdot \mathrm{IBC}$; maximum: mean $\pm \mathrm{SD}$ $=64.02 \pm 58.84$, range $=23.65 \sim 150.78{ }^{32} \mathrm{P} \mathrm{mol} / \mathrm{mol} \cdot \mathrm{IBC}$, respectively).

Glucose Incorporation Study. Both the basal $(15.2 \mathrm{nmol} / \mathrm{mg}$ protein $/ 20 \mathrm{~min}$ ) and maximally insulin-stimulated $\mathrm{D}-{ }^{14} \mathrm{C}$-glucose uptake $(24.6 \mathrm{nmol} / \mathrm{mg}$ protein $/ 20 \mathrm{~min})$ to the monolayer cultures of fibroblasts were within normal ranges (controls, basal: mean $\pm \mathrm{SD}=16.1 \pm 5.2 \mathrm{nmol} / \mathrm{mg}$ protein $/ 20 \mathrm{~min}$; maximum: mean $\pm \mathrm{SD}=24.9 \pm 7.6 \mathrm{nmol} / \mathrm{mg}$ protein $/ 20 \mathrm{~min}$, respectively). But when the uptake was expressed as percentage of the maximum uptake, the resulting insulin dose-response curve was shifted to the right (Fig. 2). Insulin concentration for a half-
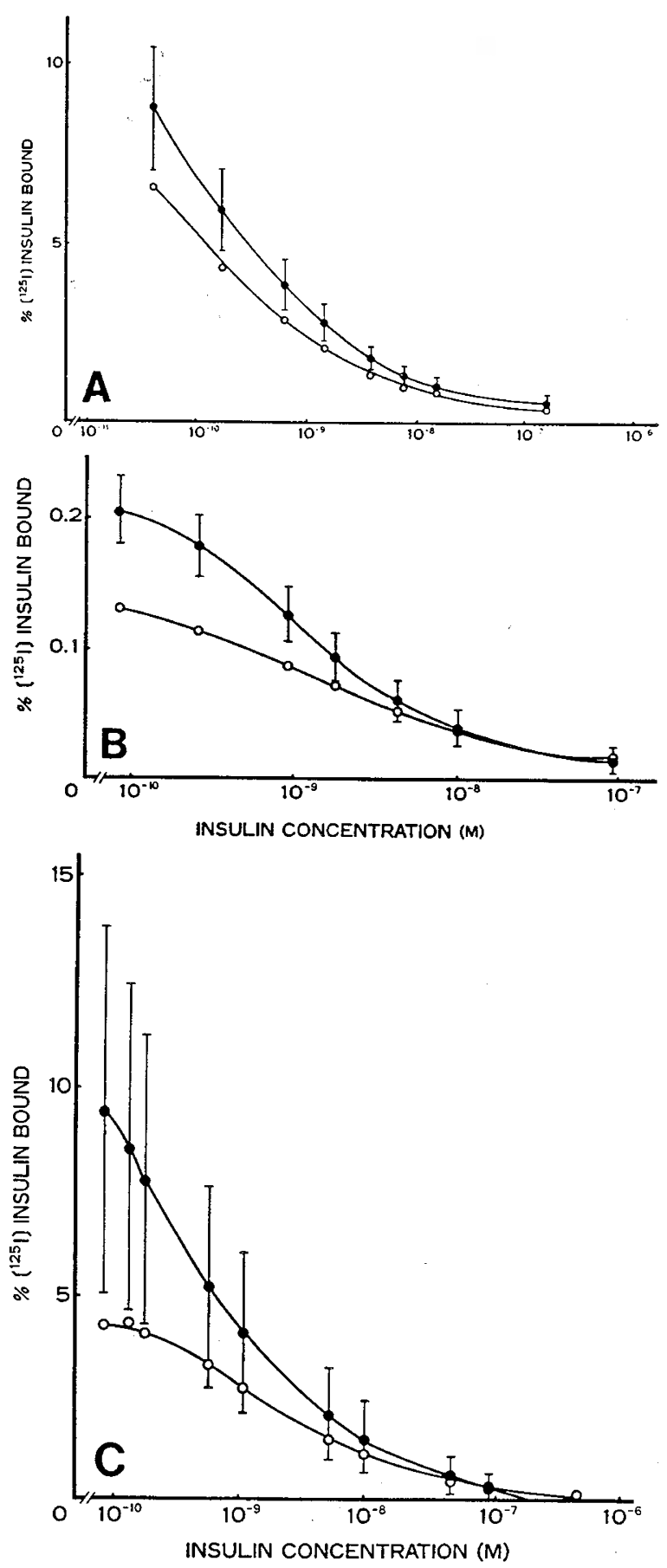

Fig. 1. ${ }^{125}$ I-insulin binding to circulating erythrocytes $(A)$, monolayer cultures of fibroblasts $(B)$, and EBV-transformed lymphocytes $(C)$ from the patient with CGL $(O)$ compared with the controls. The percentage of specific ${ }^{125}$ I-insulin bound to erythrocytes (per $3 \times 10^{9}$ cells), cultured fibroblasts (per $10^{6}$ cells), and EBV-transformed lymphocytes (per $10^{7}$ cells) is expressed as a function of total insulin concentration (M). $\bullet$, mean $\pm \mathrm{SD}$ for the respective control subjects. The controls are 11,7 , and 10 in number, respectively, and the mean $( \pm \mathrm{SD})$ age is $26.9 \pm 1.4$, $33.8 \pm 5.7$, and $37.9 \pm 17.6$ years, respectively.

maximum stimulation was between 100 and $1000 \mathrm{ng} / \mathrm{ml}$ in the patient, higher than those of the controls (mean = approximately $50 \mathrm{ng} / \mathrm{ml}$ ).

\section{DISCUSSION}

Impaired insulin action in its target tissues has been recently recognized as an important pathogenic mechanism in several 
Table 1. Maximum specific binding of ${ }^{125}$ I-insulin and stoichiometric binding parameters obtained from the insulin binding studies on circulating erythrocytes, cultured fibroblasts, and EBV-transformed lymphocytes*

\begin{tabular}{lcc}
\hline & Patient & Controls \\
\hline Erythrocytes & & $(n=11)$ \\
Specific binding & 6.6 & $(8.7 \pm 1.7 ;$ \\
$\left(\% / 3 \times 10^{9}\right.$ cells $)$ & & $6.3 \sim 11.6)$ \\
$\operatorname{Ro}(/$ cell $)$ & 82 & $(93 \pm 29)$ \\
Ke $\left(\times 10^{8} / \mathrm{M}\right)$ & 1.9 & $(2.5 \pm 1.1)$ \\
& & \\
Monolayer cultures of fibroblasts & & $(n=7)$ \\
Specific binding & 0.13 & $(0.21 \pm 0.03 ;$ \\
$\left(\% / 10^{6}\right.$ cells $)$ & & $0.15 \sim 0.30)$ \\
Ro(/cell) & 10,500 & $(8,100 \pm 2,500)$ \\
Ke $\left(\times 10^{8} / \mathrm{M}\right)$ & 1.5 & $(2.1 \pm 0.6)$ \\
ID $50\left(\times 10^{-9} \mathrm{M}\right)$ & 2.1 & $(1.3 \pm 0.3)$ \\
& & $(n=10)$ \\
EBV-transformed lymphocytes & & $(9.5 \pm 4.4 ;$ \\
Specific binding & 4.3 & $2.5 \sim 20.0)$ \\
$\left(\% / 10^{7}\right.$ cells $)$ & & $(28,000 \pm 11,000)$ \\
Ro $/$ cell $)$ & 38,000 & $(2.4 \pm 0.9)$ \\
Ke $\left(\times 10^{8} / \mathrm{M}\right)$ & 0.73 & $(0.94 \pm 0.78)$ \\
ID $\left(\times 10^{-9} \mathrm{M}\right)$ & 2.0 & \\
\hline
\end{tabular}

* The Ro and Ke were calculated from Scatchard plots by the method of De Meyts et al. $(16,17)$. Ro, $\mathrm{Ke}$, and $\mathrm{ID}_{50}$ are expressed in per cell, in $\mathbf{M}^{-1}$, and in $\mathrm{M}$, respectively. Normal data are expressed as mean $\pm \mathrm{SD}$ and range for specific binding, and mean $\pm \mathrm{SD}$ for $\mathrm{Ro}, \mathrm{Ke}$, and $\mathrm{ID}_{s 0}$.

genetic diseases with insulin resistance, including type A syndrome of insulin resistance and acanthosis nigricans (13, 19, 2426), leprechaunism $(13,27)$, Rabson-Mendenhall syndrome (28), and CGL (6-10).

In recent years, much information has been obtained about the interaction of insulin with its receptors (29-34). The insulin receptor is a heterotetrameric glycoprotein, consisting of two $\alpha$ and two $\beta$-subunits $(29,30)$. The $\alpha$-subunit $(\mathrm{Mr}=135,000)$ is an extracellularly oriented protein which contains an insulin binding site. The $\beta$-subunit ( $\mathrm{Mr}=95,000)$ is a transmembrane protein which possesses a tyrosine-specific protein kinase (31, 32). Upon binding of insulin to the receptor, the kinase is activated, resulting in the autophosphorylation of the $\beta$-subunit on tyrosine residues (33) and also in the increase of kinase activity toward some exogenous substrates such as a src-related peptide (34). It has been proposed that receptor kinase activity may play a significant role in signal transduction from insulin binding to the effector units. Therefore, defects in any of these steps could give rise to impaired insulin action and insulin resistance.

Most previous studies on insulin resistance associated with CGL have concentrated on assessing the function of the $\alpha$ subunit of insulin receptor. Oseid et al. (6) reported that insulin binding to monocytes from four patients with CGL was decreased due to a decrease in the affinity. Kodama et al. (8), studying insulin binding to monocytes from one patient with CGL, also showed decreased insulin binding. Conversely, Howard et al. (9) found normal receptor binding to cultured fibroblasts from one patient with CGL. Furthermore, WachslichtRodbard et al. (10) observed three different patterns of insulin binding to monocytes from four patients with CGL: two had decreased binding due to a decreased receptor capacity, one had normal tracer binding with a decreased receptor affinity, and one had normal insulin binding. These findings suggest that the pathogenesis of insulin resistance in CGL seems to be heterogeneous.

Euglycemic glucose clamp technique is used to assess in vivo insulin action in terms of peripheral glucose disposal $(11,35)$. Previous studies $(36,37)$ have shown that under conditions of euglycemic hyperinsulinemia, muscle tissue is primarily respon-

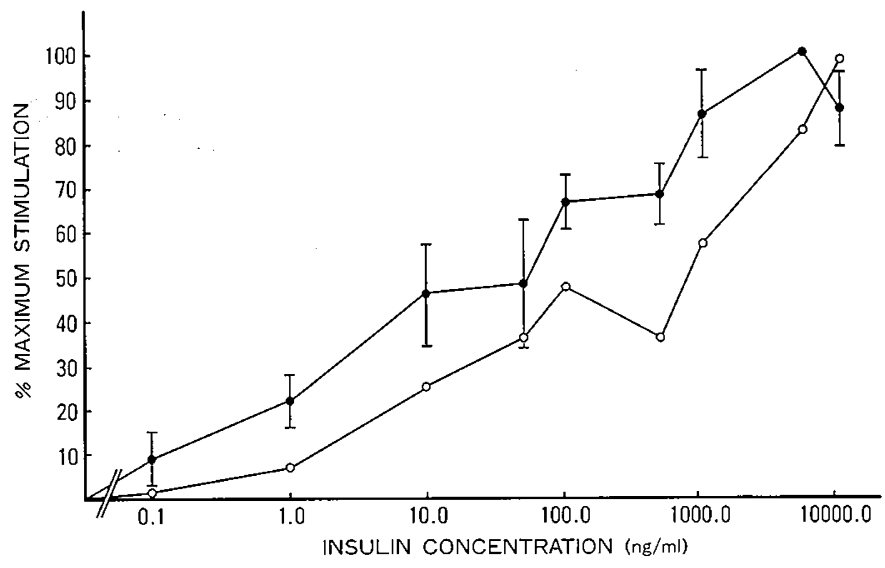

Fig. 2. Insulin stimulation of $\mathrm{D}-{ }^{14} \mathrm{C}$-glucose uptake to cultured fibroblasts from the patient with CGL $(O)$. The percentage of maximum stimulation is expressed as a function of insulin concentration $(\mathrm{ng} / \mathrm{ml})$. -, mean \pm SD for triplicate experiments on cultures from four control subjects.

sible for disposal of an intravenous glucose load. During glucose clamp studies, total glucose disposal is equal to glucose infusion rate plus HGP $(23,35)$. The estimation of HGP requires an infusion of ${ }^{3} \mathrm{H}$-glucose. Inasmuch as the use of radioactive isotopes in humans for experimental aims is restricted in our hospital, we were unable to measure HGP. However, previous studies (23) have indicated that HGP is almost completely inhibited during hyperinsulinemia, comparable to the levels obtained in this study. We assumed, therefore, that glucose infusion rate represents total glucose disposal. We assessed the extent of a rightward shift of the insulin dose-response curve for gMCR using the ratio of $\mathrm{gMCR}_{40}$ to $\max \mathrm{gMCR}$. In the patient, both the $\mathrm{gMCR}_{40} / \max \mathrm{gMCR}$ and the maximum response were decreased compared with the controls. The results suggested that insulin resistance in the patient evaluated by the glucose clamp study was characterized by decreases in both insulin sensitivity and responsiveness (38-40).

Next, in order to understand the molecular basis of the defect causing the decreases in insulin sensitivity and responsiveness shown in the glucose clamp and to see if the defect is primary or not, we performed in vitro study using circulating erythrocytes and cultured lymphocytes and fibroblasts. The study exhibited that insulin binding to the patient's erythrocytes and EBVtransformed lymphocytes was low-normal with a slight reduction in binding affinity in the latter. By contrast, insulin binding to cultured fibroblasts was decreased due to a lowered affinity. In addition, they showed a rightward shift of the insulin doseresponse curve for $\mathrm{D}^{14} \mathrm{C}$-glucose uptake (a decrease in insulin sensitivity) with no decrease in the maximum uptake. The results obtained with the cultured fibroblasts suggested a possibility that a primary defect of insulin receptor binding exists, thereby causing the decrease in insulin sensitivity. However, there were some discrepancies in insulin binding among the cells for which the reason remains unknown. Thus, we cannot at the present time formulate a conclusion as to whether or not a primary binding defect of insulin receptor exists and contributes to insulin resistance in the patient. Recently, Grigorescu et al. (41) have described structural and kinase abnormalities of erythrocyte insulin receptors from a lipodystrophic patient. However, in our patient, we could not detect any abnormality of insulin-stimulated autophosphorylation and kinase activity toward an exogenous substrate using WGA-purified receptors from EBV-transformed lymphocytes.

In addition to the decrease in insulin sensitivity, the glucose clamp study demonstrated a decrease in maximum glucose disposal. This may result from a defect at the rate-limiting step in the postbinding process of insulin-mediated glucose disposal, 
presumably a defect in the glucose transport system in muscle tissues $(39,40)$. Such a defect could not be exhibited in the cultured fibroblasts, favoring the idea that the defect may be secondary to changes in in vivo circumstances. Further studies with muscle tissue could elucidate a better understanding of the mechanisms underlying insulin resistance in the patient.

Acknowledgment. We thank Prof. Shinya Inai (Department of Clinical Pathology, Osaka Medical College, Japan) for a detailed analysis of the complement system.

\section{REFERENCES}

1. Berardinelli W 1954 An undiagnosed endocrinometabolic syndrome: Report of 2 cases. J Clin Endocrinol Metab 14:193-204

2. Sepi M 1959 Lipodystrophy and gigantism with associated endocrine manifestations: a new diencephalic syndrome? Acta Paediatr 48:555-574

3. Senior B 1961 Lipodystrophic muscular hypertrophy. Arch Dis Child 36:426431

4. Sepi M, Trygstad O 1963 Generalized lipodystrophy. Arch Dis Child 38:447453

5. Senior B, Gellis SS 1964 The syndromes of total lipodystrophy and of partial lipodystrophy. Pediatrics 33:593-612

6. Oseid S, Beck-Nielsen H, Pedersen O, Sövik O 1977 Decreased binding of insulin to its receptor in patients with congenital generalized lipodystrophy. N Engl J Med 296:245-248

7. Huseman C, Johanson A, Varma M, Blizzard RM 1978 Congenital lipodystrophy: An endocrine study in three siblings. J Pediatr 93:221-226

8. Kodama S, Kasuga M, Seki A, Ninomiya M, Sakurai T, Morishita Y, Matsuo M, Matsuo T 1978 Congenital generalized lipodystrophy with insulin-resistant diabetes. Eur J Pediatr 127:111-119

9. Howard BV, Mott DM, Hidaka H, Fields RM, Katzeff H, Howard WJ, Bennett PH 1981 Cell culture studies of a patient with congenital lipoatrophic diabetes: Normal insulin binding with alterations in intracellular glucose metabolism and insulin action. Metabolism 30:845-852

10. Wachslicht-Rodbard H, Muggeo M, Kahn CR, Saviolakis GA, Harrison LC, Flier JS 1981 Heterogeneity of the insulin-receptor interaction in lipoatrophic diabetes. J Clin Endocrinol Metab 52:416-425

11. Greenfield MS, Doberne L, Kraemer F, Tobey T, Reaven G 1981 Assessment of insulin resistance with the insulin suppression test and the euglycemic clamp. Diabetes 30:387-392

12. Radziuk J, Lickley HLA 1985 The metabolic clearance of glucose: measurement and meaning. Diabetologia 28:315-322

13. Taylor SI, Samuels B, Roth J, Kasuga M, Hedo JA, Gorden P, Brasel DE, Pokora T, Engel RR 1982 Decreased insulin binding in cultured lymphocytes from two patients with extreme insulin resistance. J Clin Endocrinol Metab 54:919-930

14. Gambhir KK, Archer JA, Bradley CJ 1978 Characteristics of human erythrocyte insulin receptors. Diabetes 27:701-708

15. Baldwin DJR, Prince $M$, Tsai $P$, Johnson $C$, Lotan R, Rubenstein AH, Olefsky JM 1981 Insulin binding, internalization, and receptor regulation in cultured human fibroblasts. Am J Physiol 241:E251-E260

16. Scatchard G 1949 The attractions of proteins for small molecules and ions. Ann NY Acad Sci 51:660-672

17. De Meyts P, Roth J 1975 Cooperativity in ligand binding: A new graphic analysis. Biochem Biophys Res Commun 66:1118-1126

18. Thakur AK, Jaffe ML, Rodbard D 1980 Graphical analysis of ligand-binding systems: evaluation by Monte Carlo studies. Anal Biochem 107:279-295

19. Grunberger C, Comi RJ, Taylor SI, Gorden P 1984 Tyrosine kinase activity of the insulin receptor of patients with type A extreme insulin resistance: Studies with circulating mononuclear cells and cultured lymphocytes. J Clin
Endocrinol Metab 59:1152-1158

20. Hedo JA, Harrison LC, Roth $\mathbf{J} 1981$ Binding of insulin receptors to lectins: Evidence for common carbohydrate determinants on several membrane receptors. Biochemistry 20:3385-3393

21. Kadowaki T, Kasuga M, Akanuma Y, Ezaki O, Takaku F 1984 Decreased autophosphorylation of the insulin receptor-kinase in streptozotocin-diabetic rats. J Biol Chem 259:14208-14216

22. Howard BV, Mott DM, Fields RM, Bennett PH 1979 Insulin stimulation of glucose entry in cultured human fibroblasts. J Cell Physiol 101:129-138

23. Rizza RA, Mandarino LJ, Gerich JE 1981 Dose-response characteristics for effects of insulin on production and utilization of glucose in man. Am J Physiol 240:E630-E639

24. Kahn CR, Flier JS, Bar RS, Archer JA, Gorden P, Martin MM, Roth J 1976 The syndromes of insulin resistance and acanthosis nigricans. N Engl J Med 294:739-745

25. Mariani S, Pedone A, Meschi F, DiNatale B, Caputo R, Broggi U, Chiumello G 1982 Insulin resistance in a child with acanthosis nigricans type A. Acta Peadiatr Scand 71:667-670

26. Grigorescu F, Flier JS, Kahn CR 1986 Characterization of binding and phosphorylation defects of erythrocyte insulin receptors in the type A syndrome of insulin resistance. Diabetes 35:127-138

27. Kashiwa H, Kawaguchi S, Takeda M, Kobayashi M, Omori Y, Eto R 1984 Insulin resistance in an infant with leprechaunism. Acta Paediatr Scand 73:701-704

28. Taylor SI, Underhill LH, Hedo JA, Roth J, Rios MS, Blizzard RM 1983 Decreased insulin binding to cultured cells from a patient with the RabsonMendenhall syndrome: Dichotomy between studies with cultured lymphocytes and cultured fibroblasts. J Clin Endocrinol Metab 56:856-861

29. Pilch PF, Czech MP 1980 The subunit structure of the high affinity insulin receptor: Evidence for a disulfide-linked receptor complex in fat cell and liver plasma membranes. J Biol Chem 255:1722-1731

30. Kasuga M, Hedo JA, Yamada KM, Kahn CR 1982 The structure of insulin receptor and its subunits. J Biol Chem 257:10392-10399

31. Ullrich A, Bell JR, Chen EY, Herrera R, Petruzzelli LM, Dull TJ, Gray A Coussens L, Liao Y-C, Tsubokawa M, Mason A, Seeburg PH, Grunfeld C, Rosen OM, Ramachandran J 1985 Human insulin receptor and its relationship to the tyrosine kinase family of oncogenes. Nature 313:756-761

32. Ebina $Y$, Ellis L, Jarnagin $K$, Edery M, Graf L, Clauser E, Ou J-H, Masiarz F, Kan YW, Goldfine ID, Roth RA, Rutter WJ 1985 The human insulin receptor cDNA: The structural basis for hormone-activated transmembrane signalling. Cell 40:747-758

33. Kasuga M, Karlsson FA, Kahn CR 1982 Insulin stimulates the phosphorylation of the 95,000-dalton subunit of its own receptor. Science 215:185-187

34. Stadtmauer LA, Rosen OM 1983 Phosphorylation of exogenous substrates by the insulin receptor-associated protein kinase. J Biol Chem 258:6682-6685

35. DeFronzo RA, Tobin JD, Andres R 1979 Glucose clamp technique: a method for quantifying insulin secretion and resistance. Am J Physiol 237:E214E223

36. DeFronzo RA, Ferrannini E, Hendler R, Wahren J, Felig P 1978 Influence of hyperinsulinemia, hyperglycemia, and the route of glucose administration on splanchnic glucose exchange. Proc Natl Acad Sci USA 75:5173-5177

37. DeFronzo RA, Jacot E, Jequier E, Maeder E, Wahren J, Felber JP 1981 The effect of insulin on the disposal of intravenous glucose: results from indirect calorimetry and hepatic and femoral venous catheterization. Diabetes 30:1000-1007

38. Kahn CR 1978 Insulin resistance, insulin insensitivity, and insulin unresponsiveness: a necessary distinction. Metabolism 27 (suppl 2):1893-1902

39. Truglia JA, Livingston JN, Lockwood DH 1985 Insulin resistance: receptor and post-binding defects in human obesity and non-insulin-dependent diabetes mellitus. Am J Med 79 (suppl 2B):13-22

40. Olefski JM, Ciaraldi TP, Kolterman OG 1985 Mechanisms of insulin resistance in non-insulin-dependent (type II) diabetes. Am J Med 79(suppl 3B):12-22

41. Grigorescu F, Jesuran M, Jean R, Mirouze J 1987 Structural abnormalities associated to a defect of the insulin receptor kinase in lipoatrophic diabetes. Diabetes 36(suppl 1):2A 